\title{
Prevalence, risk factors, and coronary angiographic profile in patients with tortuous coronary artery
}

\author{
Noha Hassanin Hanboly, Mohamed Mahmoud Abdel Ghany, \\ Sameh Mohamed Helmy El-Kaffas, Tawhid Udden Ahmed
}

Cardiovascular Department, Faculty of Medicine, Cairo University, Cairo, Egypt

\section{ARTICLE INFO}

Article history:

Submitted: 10. 32021

Accepted: 27. 4. 2021

Available online: 4. 10. 2021

\section{Kličová slova:}

Gensiniho skóre

Ischemická choroba srdeční

Vinutá věnčitá tepna

\section{SOUHRN}

Kontext: Vinutost (tortuozita) koronárních tepen je častý nález při katetrizaci koronárních tepen. I když se Ize $s$ vinutostí koronárních tepen často setkat na koronarogramech pacientů s bolestí na hrudi, uvádí se vzácně, protože není známo, zda má nebo nemá tento nález význam pro funkci srdce. Někteří autoři definují vinutost koronárních tepen jako $\geq 3$ po sobě následujících zakřivení v úhlu $45^{\circ}$ (nebo více) alespoň v jednom koronárním řečišti.

Cíle: Cílem naší studie bylo stanovit prevalenci vinutosti koronárních tepen u pacientů s koronarografickým vyšetřením provedeným v káhirské fakultní nemocnici, se zvláštním dưrazem na klinický obraz, tradiční rizikové faktory ischemické choroby srdeční (ICHS), stanovení závažnosti onemocnění podle koronarogramu pomocí Gensiniho a cévního skóre.

Pacienti a metody: Tato retrospektivní longitudinální studie se prováděla v období od listopadu 2018 do dubna 2019. Ze 788 pacientů, u nichž byla koronarografie provedena pro vyloučení ICHS, jich bylo do studie zařazeno 200 (100 s vinutostí koronárních tepen a 100 bez vinutosti koronárních tepen). Po zkontrolování popisů koronarogramů všech pacientů jsme vybrali 100 prípadů s vinutostí koronárních tepen. Jako kontroly sloužilo 100 pacientů bez vinutosti koronárních tepen. U všech pacientů byla odebrána důkladná anamnéza a provedeno fyzikální vyšetření. Následně bylo provedeno diagnostické koronarografické vyšetření femorálním nebo radiálním prístupem. Koronarogramy posoudil off-line kardiolog, který nebyl seznámen $s$ anamnézou pacientů. Vinutost koronárních tepen byla definována jako $\geq 3$ zakřivení $\left(a \geq 45^{\circ}\right.$ změna průběhu tepny) podél hlavního kmene alespoň jedné tepny, která byla přítomna v systole i diastole. Byla vypočitána Gensiniho a cévní skóre. Shromážděné údaje byly analyzovány statistickým softwarovým balíčkem IBM pro společenské vědy (Statistical Package for Social Science, SPSS), verze 23.

Výsledky: Prevalence vinutosti koronárních tepen byla 12,7 \%. S vinutostí koronárních tepen pozitivně korelovaly věk nad 65 let a ženské pohlaví. Hypertenze byla častější u pacientů s vinutostí koronárních tepen než u pacientů bez vinutosti (74 \% vs. $48 \% ; p<0,001)$. Vinutost se vyskytla častěji u r. circumflexus (left circumflex artery, LCX) (52 \%) než u r. interventricularis anterior (20\%). Aterosklerotická stenóza byla přítomna častěji při vinutém než nevinutém segmentu. Hodnoty Gensiniho a cévního skóre byly vy̌ší ve skupině bez vinutých koronárních tepen. Prevalence ICHS u pacientů s vinutostí koronárních tepen dosáhla hodnoty 48 $\%$ versus $52 \%$ u pacientů bez vinutých koronárních tepen.

Závěr: Pacienti s vinutostí koronárních tepen bez stenózy koronárních tepen aterosklerotické etiologie mohou vykazovat symptomy jako typická bolest na hrudi. Byla nalezena pozitivní korelace vinutosti koronárních tepen s hypertenzí a ženským pohlavím, ale negativní korelace s ICHS. Pacienti s vinutostí koronárních tepen mohou vykazovat symptomy jako typická bolest na hrudi, nebyla však u nich nalezena stenóza koronárních tepen. Vinutost se vyskytuje u LCX častěji než u jiných koronárních tepen. Gensiniho a cévní skóre byla vyšší než ve skupině bez vinutých koronárních tepen.

(c) 2021, ČKS.

\section{ABSTRACT}

Background: Tortuosity of the coronary arteries (CT) is a common finding during coronary artery catheterization. Although coronary tortuosity is seen frequently on coronary angiography in patients with chest pain, it is rarely reported as it is unclear whether there is a functional significance of this finding or not. Some researches define $\mathrm{CT}$ as $\geq 3$ consecutive curvatures of 45 degrees or more in at least one coronary bed. Objectives: The aim of our study was to determine the prevalence of $\mathrm{CT}$ among patients who underwent coronary angiography at Cairo University. Hospitals with specific emphasis on the clinical presentation, traditional risk factors of coronary artery disease and coronary angiographic severity studied by Gensini and vessel scores. 
Patients and methods: This retrospective longitudinal study was conducted from November 2018 to April 2019. Among 788 patients who underwent coronary angiography to rule out $C A D$, two hundred patients were enrolled (100 with CT and 100 without). We reviewed all patients' coronary angiography reports to include 100 tortuous coronary cases. Hundred patients without CT were enrolled as controls. Thorough history taking and clinical examination was done for all patients.

Diagnostic coronary angiography was performed via a femoral or radial approach. Angiograms were analyzed offline by a cardiologist, blinded to the medical history. CT was identified by $\geq 3$ bends (defined as $\geq 45^{\circ}$ change in vessel direction) along the main trunk of at least one artery, present both in systole and diastole. Gensini and vessel scores were calculated. The data collected were entered and analyzed using IBM Statistical Package for Social Science (SPSS) software version 23.

Results: The prevalence of CT was $12.7 \%$. Age more than 65 years and female gender were positively correlated with CT. Hypertension was more common in patients with $\mathrm{CT}$ than those without $(74 \% \mathrm{vs} .48 \%)$ ( $p<$ $0.001)$. Left circumflex artery (LCX) was mostly affected by tortuosity $(52 \%)$ then left anterior descending $(20 \%)$. The tortuous segment had less atherosclerotic stenosis than the non-tortuous segment. Gensini and vessel scores were higher in non-tortuous coronary arteries group. Prevalence of CAD in patients with CT was $48 \%$ versus $52 \%$ in patients without tortuous coronary arteries.

Conclusion: Patients with CT without coronary artery atherosclerotic stenosis may present with symptoms

Keywords:

Coronary artery disease

Gensini score

Tortuous coronary artery like typical chest pain. CT is positively correlated with hypertension and female gender but negatively related to CAD. Patients with CT may present with symptoms like typical chest pain yet without coronary artery stenosis. LCX is more affected by tortuosity than other coronary artery. Gensini and vessel scores were higher in non-tortuous coronary artery (NTCA) group.

\section{Introduction}

Tortuosity of the coronary arteries (CT) is a common finding on coronary angiography, however, it is rarely reported by cardiologists. ${ }^{1}$ It was found that although mild tortuosity is a common anomaly without clinical symptoms, severe tortuosity can lead to various symptoms. ${ }^{2}$ Whether tortuosity plays a role in angina is not known despite some evidence that people with severe CT and normal coronary arteries display myocardial perfusion defects. ${ }^{3}$ Clinical observations have linked tortuous arteries and veins to aging, atherosclerosis, hypertension, genetic defects and diabetes mellitus. ${ }^{4-8}$ CT had different definitions such as existing $\geq 1$ coronary artery showing $\geq 3$ consecutive curvatures $\leq 90^{\circ}$ during diastole, $\geq 2$ segments of the diastole-measured coronary arteries with $\geq 3$ curvatures of $\leq 120^{\circ}$, finding at $\geq 1$ artery along the main trunk of $<3$ bends (defined as $<45^{\circ}$ change in vessel direction), and 2 consecutive $180^{\circ}$ turns by visual estimation in a major epicardial artery. ${ }^{9-12}$ Commonly tortuosity is identified by the presence of $\geq 3$ bends (defined as $\geq 45^{\circ}$ change in vessel direction) along the main trunk of at least one coronary artery (left anterior descending [LAD], left circumflex [LCX], right coronary artery [RCA]) present in both systole and diastole (Fig. 1). ${ }^{10,13}$

Various forms of CT have been reported in clinical investigations, most commonly curving/curling, angulation, twisting, looping and kinking vessels (Fig. 2).

Tortuosity index: It was defined as the ratio of vessel curve length over the line distance between the two ends (Fig. 3). ${ }^{16}$

Tortuosity of coronary arteries occurs in patients with hypertension and myocardial infarction. ${ }^{11}$ Moreover, CT is associated with increased acute occlusion of coronary arteries, ${ }^{17}$ diabetes, ${ }^{17}$ and coronary artery fistula. ${ }^{18}$ Tortuous coronary arteries had been proposed as an indicator of ventricular dysfunction. ${ }^{10}$ While many mild tortuous arteries are left untreated, severely tortuous arteries with clinical symptoms can be treated with reconstructive surgery. ${ }^{19}$

Some studies found that CT without coronary artery obstruction or atherosclerosis may cause angina pectoris during activity or exercise test. ${ }^{11}$ Moreover, it was suggest-

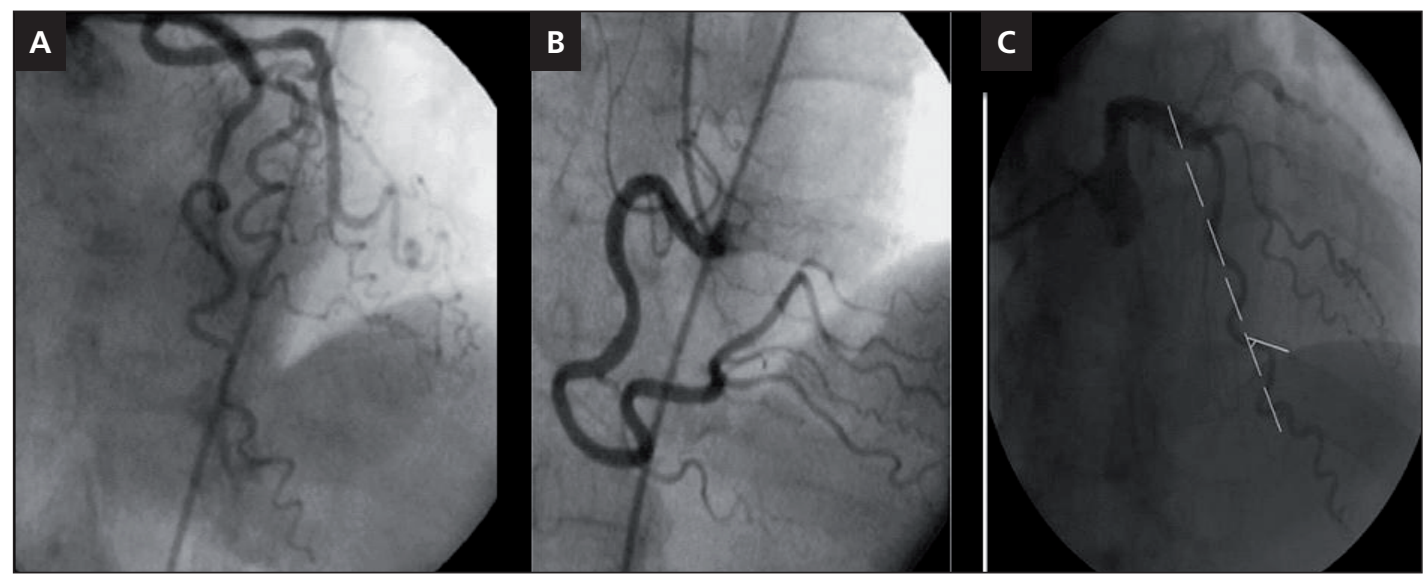

Fig. 1 - Coronary angiograms showing tortuosity in anteroposterior view with cranial angulation. ${ }^{13}$ (A) Left anterior descending and left circumflex coronary arteries. (B) Right coronary artery. (C) Diagnosis of coronary tortuosity. 


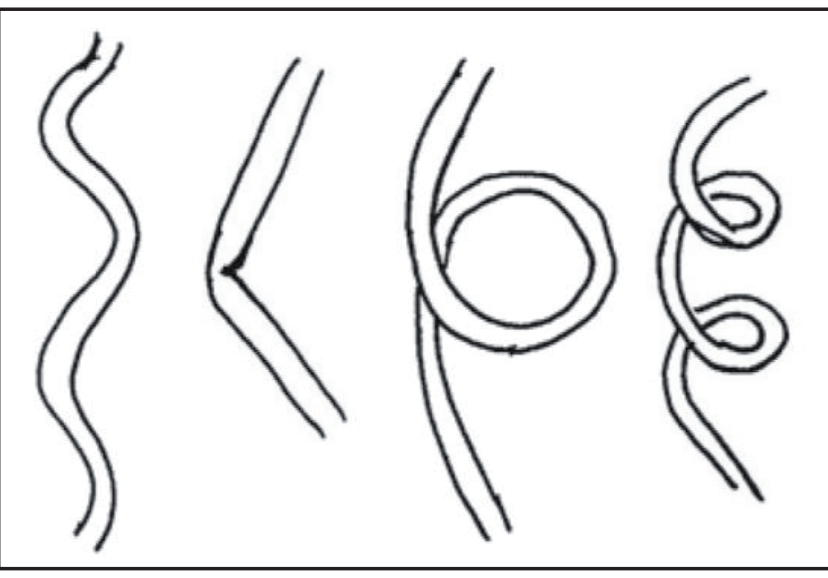

Fig. 2 - Schematics of various phenotypes of tortuous vessels. Left to right: curving, angulation/kinking, looping and spiral twisting. ${ }^{14,15}$

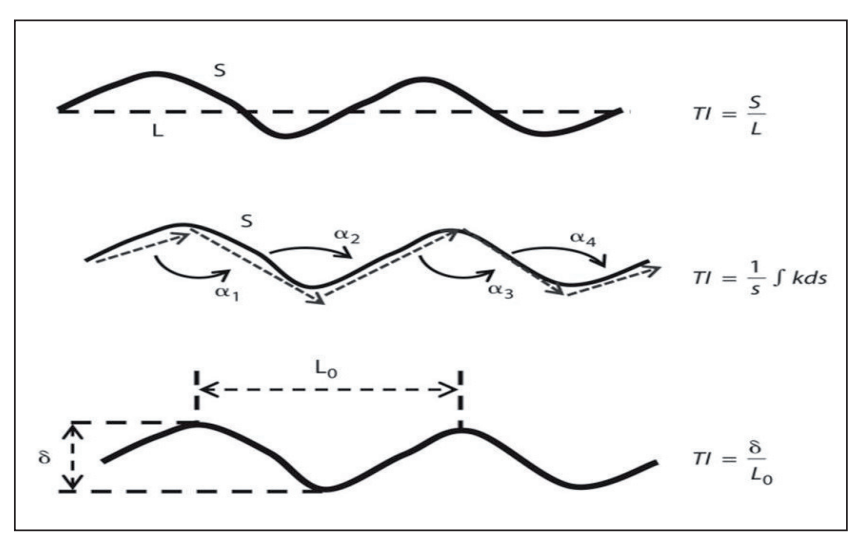

Fig. 3 - Definitions of tortuosity index. The integrated curvature of the middle panel is equal to the cumulative sum of angles $\alpha_{1}-\alpha_{4}{ }^{{ }^{16}}$

ed that CT causes alteration in blood flow and reduction in coronary artery pressure distal to the tortuous segment and can thus lead to ischemia. ${ }^{20}$

The aim of our study was to determine prevalence, clinical presentation, risk factors and coronary angiographic profile among patients with $\mathrm{CT}$.

\section{Patients and methods}

The current study was a prospective observational longitudinal study approved by the local ethical committee of Cairo University and conducted at catheterization laboratory cardiovascular department Cairo University hospitals. The study enrolled patients who underwent coronary angiography during the period from November 2018 till April 2019 to rule out coronary artery disease.

\section{Inclusion criteria}

Patients with tortuous coronary artery disease detected during cardiac catheterization.

\section{Exclusion criteria}

Post coronary artery bypass grafting, hypertrophic cardiomyopathy, coronary artery fistula, allergy to radiographic contrast, and valvular heart disease.

\section{Study design}

This study was conducted using prospectively collected data from catheterization laboratory at cardiovascular department, Cairo University hospitals. Coronary angiography reports of hundred tortuous coronary cases were reviewed. Hundred patients without tortuous coronary artery were taken as controls. History taking, clinical examination, risk factor assessment, laboratory investigations, twelve lead electrocardiogram and coronary angiography were done for all the enrolled patients. Diagnostic coronary angiography was performed via a femoral or radial approach. The technique was determined by vascular accessibility of the patient and the operator experience. Selective coronary injections were performed after intracoronary nitroglycerin and filmed in standard projections. Coronary angiograms were analyzed for CT, Gensini and vessel scores.

The coronary tortuosity was evaluated on special angulations. Left anterior descending artery (LAD) was assessed in right anterior oblique with cranial angulations, left circumflex artery (LCX) was studied in left anterior oblique with caudal angulations and right coronary artery (RCA) in right anterior oblique. Coronary tortuosity was identified by $\geq 3$ bends (defined as $\geq 45^{\circ}$ change in vessel direction) along the main trunk of at least one artery, present both in systole and diastole. ${ }^{10,13}$

\section{Vessel score}

Vessel score was calculated based on the number of vessels with significant obstructive coronary disease. The American College of Cardiology (ACC) task force definition from 2011 used $50 \%$ stenosis to define significant vessel disease. ${ }^{21}$

This definition was used for the left main coronary artery, right coronary, left anterior descending and left circumflex arteries. Scores ranged from 0 to 4, depending on the number of vessels with greater than $50 \%$ stenosis. Left main artery stenosis was scored as double vessel disease. ${ }^{22}$

\section{Gensini score}

It divides the three coronary arteries into sub-segments. The percent diameter stenosis is scored from zero to 32 depending on the severity of the stenosis. Zero if normal, 1 for $1-25 \%$, 2 for $25-50 \%, 4$ for $50-75 \%$, 8 for $75-90 \%$, 16 for $99 \%$ and 32 for total occlusion. Each segment is given a multiplying factor (from 0.5 for the distal segment to 5 for the left main coronary artery) depending on the significance of the myocardial area supplied by that segment. The sum of the scores gives the Gensini score, which provides an indication of the severity of coronary artery disease. ${ }^{23}$

\section{Statistical analysis}

The data collected were entered and analyzed using IBM statistical package for social science (SPSS) software version 23. For each indicator, frequencies or median were calculated as appropriate. The summary of statistics was presented as proportion with $95 \%$ confidence interval and means with standard deviation. Bivariate associations were examined using chi-square tests and Student's t-tests, as appropriate. For continuous variable that were 
normally distributed independent sample t-test to compare two groups and ANNOVA for comparison of more than 2 groups were used. All $p$ values with $p<0.05$ and McNemar's test $p<0.001$ were considered statistically significant.

\section{Results}

The study included 788 patients who underwent coronary angiography during the period from November 2018 till April 2019. It was a prospective observational longitudinal study. The study included two groups. A tortuous coronary artery group which included hundred patients with CT and a non-tortuous coronary artery group which included also 100 patients without CT (Fig. 4).

The average age for TCA group was 57 years (mean $56.9 \pm 10.1$ years) and for NTCA was 52 years (mean $52.9 \pm 9.7$ years). Age greater than 65 years was positively related to presence of TCA ( $p$ value $<0.001$ ) (Table 1).

Among total 200 patients, prevalence of coronary tortuosity in female was $60.4 \%$. Female gender was significantly associated with TCA $(\boldsymbol{p}<0.001)$. Systemic hypertension defined according to the recent guidelines ${ }^{24}$ was prevalent in $74 \%$ of patients with TCA. There was a significant correlation between hypertension and tortuous coronary artery ( $p$ value was $<0.001$ ) (Fig. 5).

Essential hypertension was defined as systolic blood pressure of $\geq 140 \mathrm{mmHg}$ or diastolic blood pressure of $\geq 90$

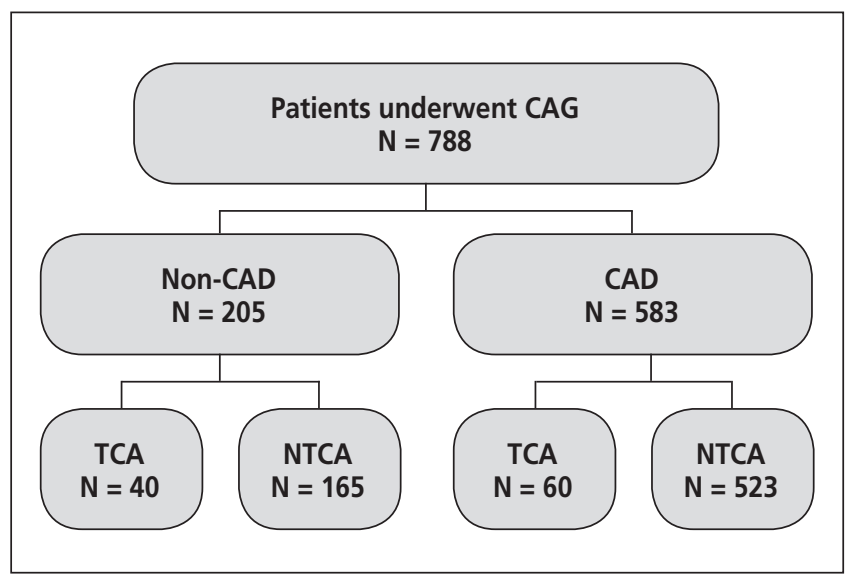

Fig. 4 - Flow diagram of patients who underwent coronary angiography (CAG). CAD - coronary artery disease; N - number; NTCA non-tortuous coronary artery; TCA - tortuous coronary artery.

Table 1 - Age and sex distribution in patients with and without coronary artery tortuosity

\begin{tabular}{l|l|l|l}
\hline & $\begin{array}{l}\text { TCA group } \\
\text { Number } 100\end{array}$ & $\begin{array}{l}\text { NTCA group } \\
\text { Number } 100\end{array}$ & $p$ value \\
\hline Female & $55 \%$ & $36 \%$ & $<0.001$ \\
\hline Male & $45 \%$ & $64 \%$ & 0.303 \\
\hline Age (years) & $56.9 \pm 10.1$ & $52.9 \pm 9.7$ & $<0.001$ \\
\hline
\end{tabular}

NTCA - non-tortuous coronary artery; TCA - tortuous coronary artery. $P$ value is significant $<0.05$.

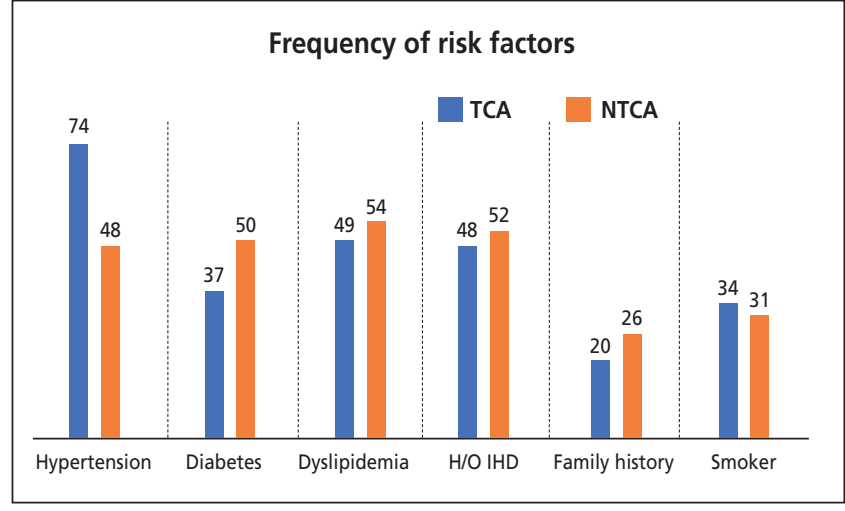

Fig. 5 - Baseline characteristics of patients with and without coronary tortuosity. H/O IHD - history of ischemic heart disease; NTCA - non-tortuous coronary artery; TCA - tortuous coronary artery.

$\mathrm{mmHg}$, or taking antihypertensive medication. Hyperlipidemia was diagnosed with total plasma cholesterol level of $\geq 200 \mathrm{mg} / \mathrm{dl}$ or low-density lipoprotein-cholesterol level of $\geq 130 \mathrm{mg} / \mathrm{dl}$ or triglyceride level of $\geq 150 \mathrm{mg} / \mathrm{dl}$, or taking cholesterol-lowering drugs.

Diabetes mellitus was defined as fasting plasma glucose $(\geq 126 \mathrm{mg} / \mathrm{dl})$ on at least 2 occasions during hospital stay or random plasma glucose $\geq 200 \mathrm{mg} / \mathrm{dl}$ with classic diabetes symptoms, or glycosylated hemoglobin $\geq 6.5 \%$ or the use of blood glucose lowering agents. ${ }^{25}$ Table 2 shows the baseline characteristics of the study groups.

\section{Clinical presentation}

It was found that $56 \%$ of patients with TCA had history of typical chest pain (TCP) and $44 \%$ of them had history of nonspecific chest pain. Patients with TCA without CAD (obstructive) mostly presented with atypical chest pain. On the other side, $80 \%$ of patients with NTCA had typical chest pain versus $20 \%$ with nonspecific chest pain. Patients with TCA group complained of nonspecific chest pain more than NTCA group (Fig. 6).

Table 3 showed the laboratory findings in the two study groups.

Among 788 patients who underwent coronary angiography 100 patients had TCA (12.69\%), of which 60 patients had significant coronary artery disease (Fig. 7).

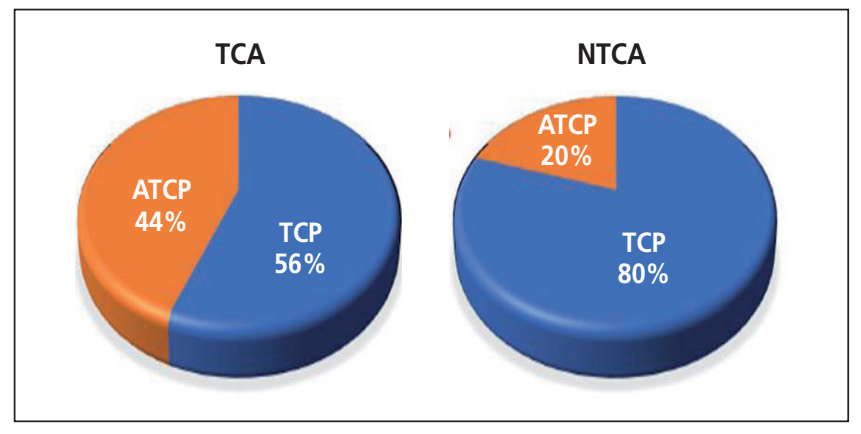

Fig. 6 - Clinical presentation of patients with TCA and NTCA. ATCP - atypical chest pain; NTCA - non-tortuous coronary artery; TCA tortuous coronary artery; TCP - typical chest pain. 


\begin{tabular}{|c|c|c|c|c|}
\hline \multicolumn{2}{|l|}{ Variables } & TCA & NTCA & $p$ value \\
\hline \multicolumn{2}{|l|}{ Hypertension } & $74.0 \%$ & $48.0 \%$ & 0.001 \\
\hline \multicolumn{2}{|l|}{ Diabetes } & $37.0 \%$ & $50.0 \%$ & 0.064 \\
\hline \multicolumn{2}{|l|}{ Dyslipidemia } & $49.0 \%$ & $54.0 \%$ & 0.479 \\
\hline \multicolumn{2}{|l|}{ Family history of heart disease } & $20.0 \%$ & $26.0 \%$ & 0.313 \\
\hline \multirow[t]{2}{*}{ Smoker } & Yes & $34.7 \%$ & $31.6 \%$ & \multirow[t]{2}{*}{0.76} \\
\hline & No & $65.3 \%$ & $68.4 \%$ & \\
\hline \multirow[t]{2}{*}{ Chest pain } & ATCP & $44.0 \%$ & $20.0 \%$ & \multirow[t]{2}{*}{0.001} \\
\hline & TCP & $56.0 \%$ & $80.0 \%$ & \\
\hline \multicolumn{2}{|l|}{ Ischemic heart disease } & $48.0 \%$ & $52.0 \%$ & 0.571 \\
\hline
\end{tabular}

ATCP - atypical chest pain; NTCA - non-tortuous coronary artery; TCA - tortuous coronary artery; TCP - typical chest pain. Values are expressed as $(\%) ; p$ value is significant $<0.05$.

\begin{tabular}{l|l|l|l|}
\hline \multicolumn{2}{|l|}{ Table 3 - Laboratory findings for both TCA and NTCA groups } & & p value \\
\hline & TCA & NTCA & NS \\
\hline Creatinine $(\mathrm{mmol} / \mathrm{L})$ & $0.93 \pm 0.47$ & $0.98 \pm 0.36$ & NS \\
\hline Urea $(\mathrm{mg} / \mathrm{dL})$ & $28.36 \pm 9$ & $31.32 \pm 8.5$ & NS \\
\hline Glucose $(\mathrm{mg} / \mathrm{dL})$ & $93 \pm 23$ & $89 \pm 34$ & NS \\
\hline Total cholesterol $(\mathrm{mg} / \mathrm{dL})$ & $172(107-305)$ & $185(121-323)$ & NS \\
\hline Triglycerides $(\mathrm{mg} / \mathrm{dL})$ & $138(82-355)$ & $144(71-442)$ & \\
\hline
\end{tabular}

NS - non-significant; NTCA - non-tortuous coronary artery; TCA - tortuous coronary artery.

\begin{tabular}{|c|c|c|c|}
\hline & Tortuous segment & Non-tortuous segment & $p$ value \\
\hline No stenosis & $84.0 \%$ & $41.0 \%$ & $<0.001$ \\
\hline$<50 \%$ stenosis & $7.0 \%$ & $6.0 \%$ & 0.321 \\
\hline $50 \%$ to $<70 \%$ stenosis & $6.0 \%$ & $21.0 \%$ & $<0.001$ \\
\hline$>70 \%$ stenosis & $3.0 \%$ & $32.0 \%$ & $<0.001$ \\
\hline
\end{tabular}

Values are expressed in \%; $p$ value significant $<0.05$

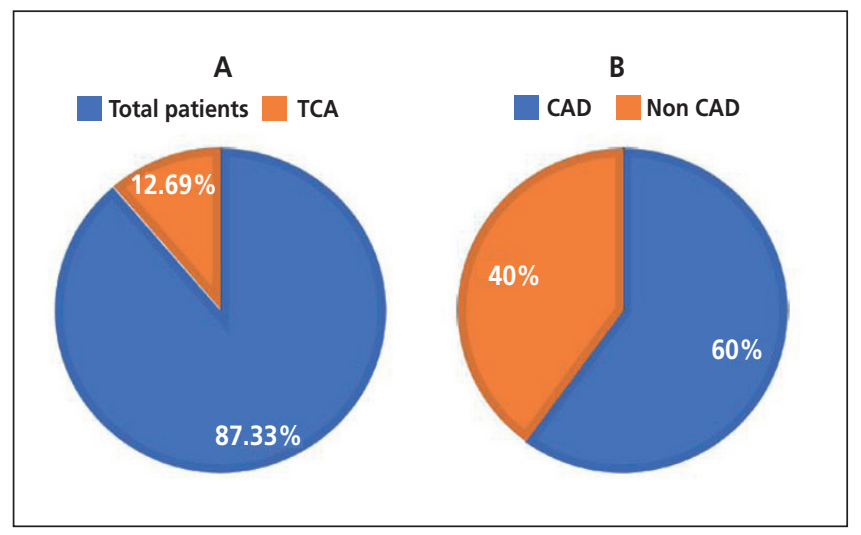

Fig. 7 - (A) Prevalence of TCA in our study. (B) Prevalence of coronary artery disease among TCA group. CAD - coronary artery disease; TCA - tortuous coronary artery.
On the other hand, among the non -tortuous coronary artery (NTCA group), 523 of them had significant coronary artery disease and 165 had no coronary artery lesions.

Among 100 patients with tortuous coronary arteries the prevalence of affected coronary artery was LAD $20 \%$, LCX $52 \%$, RCA $9 \%$, LAD-LCX $10 \%$, LAD-RCA $2 \%$, LCX-RCA $6 \%$ and triple vessel disease $1 \%$. LCX was mostly affected by tortuosity than other coronary vessels. The tortuous segment had less atherosclerotic stenosis than the non-tortuous segment. Table 4 shows the percentage of coronary artery stenosis in the study groups.

Coronary angiography was analyzed using Gensini score and Vessel score in both study groups (Table 5).

Figure 8 represents prevalence of single, double, and triple vessel diseases among the study groups. 
Table 5 - Gensini and vessel scores for tortuous and non-tortuous coronary artery groups

\begin{tabular}{l|l|l|l}
\hline Score & TCA group $N=100$ & NTCA group $N=100$ & $p$ value \\
\hline Gensini score & 19.18 & 21.16 & 0.607 \\
\hline Vessel score 1-3 & 0.79 & 1.08 & 0.018 \\
\hline
\end{tabular}

Both Gensini and Vessel scores expressed as mean; $p$ value significant at $p<0.05$. NTCA - non-tortuous coronary artery; TCA - tortuous coronary artery.

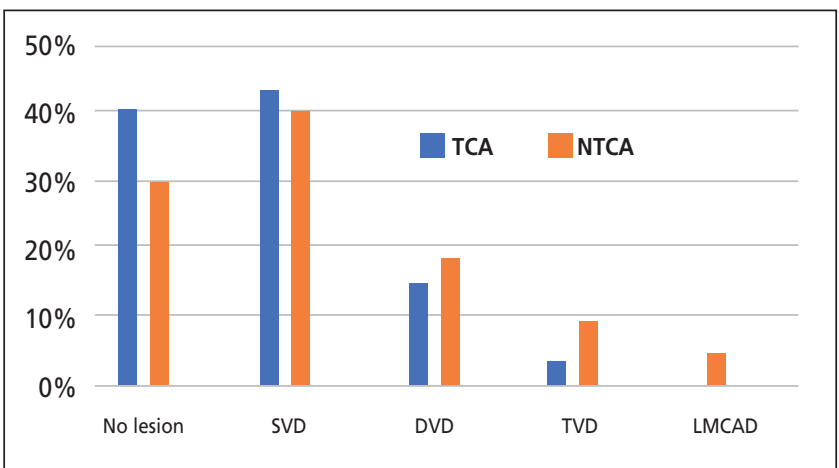

Fig. 8 - Coronary angiographic findings in patients with and without tortuous coronary artery. DVD - double vessel disease; LMCAD - left main coronary artery disease; NTCA - non-tortuous coronary artery; SVD - single vessel disease; TCA - tortuous coronary artery; TVD - triple vessel disease.

\section{Discussion}

Coronary tortuosity is a common coronary angiography finding. However, the exact clinical implication and the coronary angiographic profile in these patients needs further study. The purpose of this study was to study the clinical presentation, risk factors, and severity of coronary artery disease studied by validated Gensini and Vessel scores in patients with $\mathrm{CT}$.

Tortuosity is identified by the presence of $\geq 3$ bends (defined as $\geq 45^{\circ}$ change in vessel direction) along the main trunk of at least one coronary artery (LAD, LCX and RCA) present in both systole and diastole. ${ }^{10,13}$ In another study tortuosity was defined as two continuous endings with an angle of $180^{\circ}$ in a major epicardial artery via visual estimation during coronary angiography. ${ }^{26}$

Contrary to our study which found that age above 65 years was positively correlated with coronary tortuosity, Groves et al. ${ }^{12}$ did not find any correlation between aging (over 65 years) and coronary tortuosity. However, the same study ${ }^{12}$ found that CT was significantly more prevalent among females, a finding that was also supported by our study.

Artery tortuosity may be associated with age, hypertension, atherosclerosis, and genetic syndrome. ${ }^{6,27} \mathrm{He}-$ modynamic forces are important modulators of vascular structure. Arteries may become tortuous due to decreased axial strain and hypertensive pressure in an elastic cylindrical arterial model. ${ }^{28}$ Decreased axial strain results in arterial tortuosity due to aberrant matrix metalloproteinase activity. ${ }^{29}$ The current study found significant correlation between hypertension and coronary tortuosity ( $p$ value was $<0.001)$. The close association between hypertension and CT is expected because CT might be a form of artery remodeling induced by hypertension due to increased coronary pressure and blood flow. CT could thus be recognized as an adaptive change of hypertension.

Significant number of patients with CT had nonspecific chest pain. It is possible that severe CT causes myocardial perfusion abnormalities. The association of tortuosity with ischemia warrants further investigation with prospective studies utilizing functional assessments such as pressure wire studies, coronary flow reserve, myocardial perfusion imaging and myocardial resonance studies.

CT can result in a reduction in coronary perfusion pressure, leading to ischemia in the absence of luminal narrowing. It has been suggested that CT causes an alteration in blood flow and reduces the coronary artery pressure distal to the tortuous segment. ${ }^{11}$ In another study Li et al. ${ }^{30}$ showed that $\mathrm{CT}$ can result in decreased coronary blood pressure. Therefore, severe CT may cause myocardial ischemia and angina pectoris.

A recent study investigated tissue perfusion in myocardial territories supplied by tortuous coronary arteries and concluded that tortuous coronary arteries have higher thrombolysis in myocardial infarction frame count and lower myocardial blush grade, suggesting impaired epicardial and microvascular coronary flow. ${ }^{31}$ Coronary tortuosity has a minor impact on coronary blood flow at rest; however, during activity, patients with $\mathrm{CT}$ may lack the capacity to change distal resistance to compensate for additional tortuosity-generated resistance, which may lead to improper blood supply. ${ }^{32}$

A previous study found that patients with non-obstructive epicardial disease and reversible myocardial perfusion defects on contrast stress echocardiography had more severe coronary tortuosity. This finding gives some evidence for tortuosity precipitating myocardial ischemia. ${ }^{33}$

Our study found that prevalence or CT among the patients who underwent coronary angiography because of chest pain was $12.69 \%$. Among the arteries affected by coronary tortuosity, the higher prevalence was LCX (52\%). This was concordant with a study that evaluated coronary artery tortuosity in spontaneous coronary artery dissection and concluded that tortuosity was most often observed in the left circumflex artery, followed by the left anterior descending and the right coronary artery. ${ }^{34}$

In our study, we found that $84 \%$ of tortuous coronary arteries group did not have any stenosis in tortuous segment ( $p$ value $<0.001$ ) and only $3 \%$ of them had more than $70 \%$ stenosis in tortuous segment. The prevalence of triple vessel disease and left main coronary artery disease was higher in NTCA group than in TCA group.

Although microvascular network of tortuous coronary arteries was not investigated in our study we found that 
both Gensini and Vessel scores were higher in NTCA group than TCA group.

Our results were close to $\mathrm{Li}$ et al. ${ }^{35}$ study that showed a $39.1 \%$ prevalence of CT among the study group. Moreover the same study found higher incidence of CT in female patients. CT was positively correlated with essential hypertension and negatively correlated with CAD.

Concordant with Chiha et al. ${ }^{36}$ who found that Extent, Gensini and Vessel scores were lower in severe coronary tortuosity, we found that Gensini score was 19.18 and 21.16 for TCA and NTCA groups, respectively ( $p$ value was $0.607)$. Moreover, Vessels score was 0.79 and 1.08 for the TCA and NTCA groups, respectively ( $p$ value was 0.018 ).

\section{Conclusion}

Female gender and age above 65 years were strongly associated with coronary artery tortuosity. Hypertension was the most prevalent risk factor in patients with coronary tortuosity. Patients with TCA may present with symptoms like typical chest pain without coronary artery stenosis. LCX is more affected by tortuosity than another coronary artery. Gensini and Vessel scores were higher in NTCA group.

\section{Recommendations}

Future researchers should be directed towards recruiting larger number of patients to validate the risk factors of tortuous coronary artery. Moreover further research is required to assess hemodynamic changes like coronary pressure and shear stress in tortuous segments. More consideration should be given to the perfusion of corresponding microvascular network of tortuous coronary arteries.

\section{Acknowledgements}

We would like to thank to the Cardiac Catheterization Laboratory staff for their continued support and help.

\section{Conflict of interest}

None declared.

\section{References}

1. Helisch ASW. Arteriogenesis: the development and growth of collateral arteries. Microcirculation 2003;10:83-97.

2. Han HC. Twisted Blood Vessels: Symptoms, Etiology and Biomechanical Mechanisms. J Vasc Res 2012;49:185-197.

3. Gaibazzi N, Rigo F, Reverberi C. Severe coronary tortuosity or myocardial bridging in patients with chest pain, normal coronary arteries, and reversible myocardial perfusion defects. Am J Cardiol 2011;108:973-978.

4. Del Corso L, Moruzzo D, Conte B, et al. Tortuosity, kinking, and coiling of the carotid artery: expression of atherosclerosis or aging? Angiology 1998;49:361-371.

5. Hiroki M, Miyashita K, Oda M. Tortuosity of the white matter medullary arterioles is related to the severity of hypertension. Cerebrovasc Dis 2002;13:242-250.

6. Pancera P, Ribul M, Presciuttini B, Lechi A. Prevalence of carotid artery kinking in 590 consecutive subjects evaluated by echocolor Doppler. Is there a correlation with arterial hypertension? J Intern Med 2000;248:7-12.
7. Callewaert BL, Willaert A, Kerstjens-Frederikse WS, et al. Arterial tortuosity syndrome: clinical and molecular findings in 12 newly identified families. Hum Mutat 2008;29:150-158.

8. Owen CG, Newsom RS, Rudnicka AR, et al. Diabetes and the tortuosity of vessels of the bulbar conjunctiva. Ophthalmology 2008;115:e27-e32.

9. Gaibazzi N, Rigo F, Reverberi C. Severe coronary tortuosity or myocardial bridging in patients with chest pain, normal coronary arteries, and reversible myocardial perfusion defects. Am J Cardiol 2011;108:973-978.

10. Turgut O, Yilmaz A, Yalta K, et al. Tortuosity of coronary arteries: an indicator for impaired left ventricular relaxation? Int J Cardiovasc Imaging 2007;23:671-677.

11. Zegers ES, Meursing BTJ, Zegers EB, Oude Ophuis AJM. Coronary tortuosity: a long and winding road. Neth Heart J 2007;15:191-195.

12. Groves SS, Jain AC, Warden BE, et al. Severe coronary tortuosity and the relationship to significant coronary artery disease. WV Med J 2009;105:14-17.

13. Zaacks SM, Allen JE, Calvin JE, et al. Value of the American College of Cardiology/American Heart Association stenosis morphology classification for coronary interventions in the late 1990s. Am J Cardiol 2002;82:43-49.

14. Wang L, Zhao F, Wang D, et al. Pressure Drop in Tortuosity/ Kinking of the Internal Carotid Artery: Simulation and Clinical Investigation. Biomed Res Int 2016;2016:2428970.

15. Yu J, Qu L, Xu B, et al. Current Understanding of Dolichoarteriopathies of the Internal Carotid Artery. Int J Med Sci 2017;14:772-784.

16. Hoi $Y, G a o L$, Tremmel $M$, et al. In vivo assessment of rapid cerebrovascular morphological adaptation following acute blood flow increase. J Neurosurg 2008;109:1141-1147.

17. Ellis SG, Vandormael MG, Cowley MJ, et al. Coronary morphologic and clinical determinants of procedural outcome with angioplasty for multivessel coronary disease. Implications for patient selection. Multivessel Angioplasty Prognosis study group. Circulation 1990;82:1193-1202.

18. Said SA, Hofman MB, Beek AM, et al. Feasibility of cardiovascular magnetic resonance of angiographically diagnosed congenital solitary coronary artery fistulas in adults. J Cardiovasc Magn Reson 2007;9:575-583.

19. Aleksic M, Schütz G, Gerth S, Mulch J. Surgical approach to kinking and coiling of the internal carotid artery. J Cardiovasc Surg (Torino) 2004;45:43-48.

20. APD Estrada, de Oliveira LR, Humberto VJ. Coronary tortuosity and its role in myocardial ischemia in patients with no coronary obstructions. Int J Cardiovasc Sci 2017;30:163-170.

21. Levine GN, Bates ER, Blankenship AC, et al. ACCF/AHA/ SCAI Practice Guideline 2011 ACCF/AHA/SCAI Guideline for Percutaneous Coronary Intervention. A Report of the American College of Cardiology Foundation/American Heart Association Task Force on Practice Guidelines and the Society for Cardiovascular Angiography and Interventions. Circulation 2011;124:e574-e651.

22. Norgaz T, Hobikoglu G, Aksu H, et al. Retinopathy is related to the angiographically detected severity and extent of coronary artery disease in patients with type 2 diabetes mellitus. Int Heart J 2005;46:639-646.

23. Gensini GG. A more meaningful scoring system for determining the severity of coronary heart disease. Am J Cardiol 1983;51:606.

24. Thomas U, Claudio B, Fadi C, et al. 2020 International Society of Hypertension Global Hypertension Practice Guidelines. Hypertension 2020;75:1334-1357.

25. American Diabetes Association. Diagnosis and classification of diabetes mellitus. Diabetes Care 2010;33:S62-S69.

26. Saeed B, Banerjee S, Brilakis ES. Percutaneous coronary intervention in tortuous coronary arteries: associated complications and strategies to improve success. J Intervent Cardiol 2008;21:504-511.

27. Satish G, Nampoothiri S, Kappanayil M. Images in cardiovascular medicine. Arterial tortuosity syndrome: phenotypic features and cardiovascular manifestations. Circulation 2008;117:e477-e478. 
28. Han HC. A biomechanical model of artery buckling. J Biomech 2007;40:3672-3678.

29. Jackson ZS, Dajnowiec D, Gotlieb Al, Langille BL. Partial offloading of longitudinal tension induces arterial tortuosity. Arterioscler Thromb Vasc Biol 2005;25:957-962.

30. Yang L, Xiuxian L, Zhiyong L, et al. Impact of coronary tortuosity on coronary pressure and wall shear stress: an experimental study. Mol Cell Biomech 2017;14:213-219.

31. Kerim E, Emir B, Ebru S, et al. Assessment of Myocardial Perfusion by Angiographic Methods in Tortuous Coronary Arteries. Angiology 2020;71:616-620.

32. Xie $X$, Wang $Y$, Zhu H, et al. Impact of coronary tortuosity on coronary blood supply: a patient-specific study. PLoS One 2013;8:e64564.
33. Gaibazzi N, Rigo F, Reverberi C. Severe coronary tortuosity or myocardial bridging in patients with chest pain, normal coronary arteries, and reversible myocardial perfusion defects. Am J Cardiol 2011;108:973-978.

34. Mackram F, Raviteja R, Marysia S, et al. Coronary Artery Tortuosity in Spontaneous Coronary Artery Dissection Angiographic Characteristics and Clinical Implications. Circ Cardiovasc Interv 2014;7:656-662.

35. Li Y, Shen C, Ji Y, et al. Clinical implication of coronary tortuosity in patients with coronary artery disease. PLoS One 2011;6:e24232.

36. Chiha J, Mitchell P, Gopinath B, et al. Gender differences in the prevalence of coronary artery tortuosity and its association with coronary artery disease. Int J Cardiol Heart Vasc 2016;14:23-27. 